Gulawentah: Jurnal Studi Sosial

ISSN 2528-6293 (Print); ISSN 2528-6871 (Online)

Vol. 4, No. 1, Juli 2019, Hal 1-12

Tersedia Online: http://e-journal.unipma.ac.id/index.php/gulawentah

\title{
Upaya Peningkatan Kompetensi Guru dalam Menyusun Silabus dan RPP Melalui Supervisi Akademik Berkelanjutan di SDN 2 Ngadisanan Sambit
}

\author{
Bambang Mardjoko \\ SD Negeri 2 Ngadisanan, Ponorogo, Indonesia \\ Email: bangjok787@gmail.com
}

\begin{abstract}
Abstrak
Penelitian ini bertujuan untuk 1) mendiskripsikan pelaksanaan kompetensi guru dalam menyusun silabus dan RPP melalui supervisi akademik berkelanjutan di SDN 2 Ngadisanan Sambit. 2) mengetahui peningkatan kompetensi guru dalam menyusun silabus dan RPP melalui supervisi akademik berkelanjutan. Penelitian ini dilaksanakan di SD Negeri 2 Ngadisanan, Sambit, Ponorogo selama enam bulan tahun 2019. Subyek guru kelas satu sampai enam. Pengambilan data secara diskriptif kualitatif, jenis penelitian tindakan sekolah (PTS). Hasil penelitian menunjukkan bahwa dengan supervisi akademik dapat meningkatkan kompetensi guru menyusun Silabus dan RPP. Peningkatan ini dibuktikan pada tahap praobservasi menunjukan bahwa instrumen telaah RPP kemampuan guru dalam kategori kurang, nilai 65\% dibandingkan dengan kompetensi lain. Pada siklus I ada peningkatan, nilai rata-rata kompetensi guru pada telaah RPP sudah mencapai $80 \%$ dengan kreteria cukup. Kompetensi guru dalam penyusunan RPP dan silabus pada siklus 2 setelah diadakan supervisi akademik dan tindak lanjut nilai ratarata telah mencapai $85 \%$ pada telaah RPP dengan kreteria baik.
\end{abstract}

Kata kunci: kompetensi; RPP; Supervisi Akademik

\section{Teacher Competency Improvement Efforts in Creating Syllabus and RPP (Lesson Plan) Through Sustainable Academic Supervision at SDN 2 Ngadisanan Sambit}

\begin{abstract}
This research aims to 1) describe the implementation of teacher competencies in preparing syllabus and lesson plans (RPP) through sustainable academic supervision at SDN 2 Ngadisanan, Sambit. 2) knowing the improvement of teacher competencies in preparing syllabus and lesson plans through sustainable academic supervision. This research was carried out in SD Negeri 2 Ngadisanan, Sambit, Ponorogo for 6 months in 2019. Subjects were teacher from first grade until sixth grade. Data collection was descriptive qualitative, type of school action research (PTS). The results of the study indicated that academic supervision could improve competencies of the teacher in preparing Syllabus and lesson plans (RPP). This increase was evidenced in the preobservation stage, indicating that the instrument for RPP review of the ability of teachers in the category was less, the value was $65 \%$ compared to other competencies. In the Cycle I (first cycle) there was an increase, the average value of teacher competencies in the lesson plan study had reached $80 \%$ with sufficient criteria. Teacher competencies in the preparation of RPP and syllabus in Cycle II (second cycle) after academic supervision and followed up on average scores had reached $85 \%$ in the lesson plan review with good criteria.
\end{abstract}

Keywords: Competency; lesson plan; academic supervision

DOI: 10.25273/gulawentah.v4i1.4863

Copyright $@ 2019$ Universitas PGRI Madiun

All rights reserved. 


\section{2 - Gulawentah: Jurnal Studi Sosial}

\section{Pendahuluan}

Sesuai dengan tujuan pendidikan dalam pelaksanaanya maka disusunlah Kurikulum. Menurut UU No. 20 Tahun 2003 pasal 1 ayat (19). yang dimaksud kurikulum adalah seperangkat rencana dan pengaturan mengenai tujuan, di dalamnya terdapat isi dan bahan pembelajaran serta cara yang digunakan sebagai pedoman penyelenggaraan kegiatan pembelajaran untuk mencapai tujuan pendidikan nasional. Dalam Permendikbud No. 81a Tahun 2013 lampiran 1 dijelaskan bahwa kurikulum nasional yang dikembangkan dan dilaksanakan oleh satuan pendidikan diwujudkan dalam bentuk Kurikulum Tingkat Satuan Pendidikan (KTSP ). Bisa disimpulkan bahwa KTSP adalah seperangkat rencana yang didalamnya terdapat pengaturan pengenai tujuan, isi, dan bahan pelajaran serta cara yang digunakan sebagai pedoman penyelenggaraan kegiatan pembelajaran yang sudah operasional untuk mencapai tujuan pendidikan tertentu yang disusun dan dilaksanakan oleh masing masing satuan pendidikan.

Dalam pendidikan kurikulum memiliki berbagai macam fungsi dan sangat berperan dalam kegunannya. Fungsi Kurikulum adalah sebagai berikut: 1. Fungsi Penyesuaian (the adjustive or adaptive function) : Kurikulum berfungsi sebagai penyesuain adalah kemampuan untuk menyesuaikan diri dengan perubahan yang terjadi dilingkungannya karna lingkungan bersifat dinamis artinya dapat berubah-ubah. 2. Fungsi Integrasi (the integrating function) : Kurikulum berfungsi sebagai penyesuain mengandung makna bahwa kurikulum merupakan alat pendidikan yang mampu menghasilkan pribadi-pribadi yang utut yang dapat dibutuhkan dan berintegrasi di masyarakat. 3. Fungsi Diferensiasi (the diferentiating function) : Kurikulum berfungsi sebagai diferensiansi adalah sebagai alat yang memberikan pelayanan dari berbagai perbedaan disetiap siswa yang harus dihargai dan dilayani. 4. Fungsi Persiapan (the propaeduetic function) : Kurikulum berfungsi sebagai persiapan yang mengandung makna bahwa kurikulum sebagai alat pendidikan mampu mempersiapkan siswa kejenjang selanjutnya dan juga dapat mempersiapkan diri dapat hidup dalam masyarakat, jika tidak melanjukan pendidikan. 5. Fungsi Pemilihan (the selective function) : Kurikulum berfungsi sebagai pemilihan adalah memberikan kesempatan bagi siswa untuk menentukan pilihan program belajar yang sesuai dengan minat dan bakatnya. 6. Fungsi Diagnostik (the diagnostic function) : Kurikulum sebagai diagnostik mengandung makna bahwa kurikulum adalah alat pendidikan yang mampu mengarahkan dan memahami potensi siswa serta kelemahan dalam dirinya.

Menurut (Sudin, 2008) faktor penghambat dalam efektifitas pembinaan guru lebih pada faktor pribadi; yakni ketidakmampuan para pengawas pendidikan untuk melaksanakan pembinaan professional guru secara efektif karena keterbatasan pengetahuan, keterampilan, dan bahkan kepribadiannya. Beberepa pertama, guru belum memiliki kecakapan atau keterampilan menyusun perangkat persiapan pembelajaran. Atau yang kedua, guru enggan untuk membuatnya. Kedua alasan 
inilah yang menarik untuk disimak, mengapa guru masih enggan untuk menyusun perangkat persiapan pembelajaran? Padahal, ia telah mendapat gaji rutin (bagi yang berstatus PNS) dalam jumlah yang relatif cukup, terlebih lagi, bagi guru yang sudah lolos sertifikasi, ia telah mendapat tunjangan sertifikasi guru dalam jumlah yang lumayan. Dengan nada seloroh, ada guru yang mengungkapkan alasan, yaitu "waktu yang digunakan untuk menyusun persiapan pembelajaran sering lebih lama daripada waktu penyajiannya”. Bila demikian halnya, maka alasan yang ketiga, ialah bahwa guru tidak punya cukup waktu untuk membuatnya (Rosilawati, 2014).

Guru harus mampu berperan sebagai desainer (perencana), implementor (pelaksana), dan evaluator (penilai) kegiatan pembelajaran. Guru merupakan faktor yang paling dominan karena di tangan gurulah keberhasilan pembelajaran dapat dicapai. Kualitas mengajar guru secara langsung maupun tidak langsung dapat mempengaruhi kualitas pembelajaran pada umumnya. Banyak masasalah pembelajaran yang terjadi di lapangan begitu juga di SDN 2 Ngadisanan Sambit masih ditemukan adanya guru yang kurang mampu menyusun RPP yang dengan berbagai alasan, dan bagi guru yang sudah mampu menyusun RPP akan tetapi masih ditemukan adanya guru yang belum melengkapi komponen tujuan pembelajaran dan penilaian (soal, skor dan kunci jawaban), serta langkah-langkah kegiatan pembelajarannya masih belum sesuia dengan yang diharapkan terutama dalam pembelajaran Ilmu Pengetahuan Sosial. Masalah yang lain yaitu sebagian besar guru khususnya Guru Tidak Tetap (GTT) belum mendapatkan pelatihan pengembangan RPP. Selama ini guru-guru tidak tetap sedikit/jarang mendapatkan kesempatan untuk mengikuti berbagai Diklat Peningkatan Profesionalisme Guru dibandingkan guru yang sudah PNS. Hal ini menyebabkan banyak guru yang belum tahu dan memahami penyusunan/pembuatan RPP secara baik/lengkap. Hampir semua guru di SD Negeri 2 Ngadisanan Sambit mengadopsi RPP orang lain. Bahkan materi dalam RPP tidak disusuaikan dengan keadaan lingkungan sosial sekolah juga metode yang digunakan tidak menarik motivasi belajar anak . Perbedaan karakteristik siswa tidak diperhatikan, apalagi dalam pelaksanaan pembelajaran Ilmu Pengetahuan Sosial. Hal ini peneliti ketahui pada saat mengadakan supervisi akademik (supervisi kunjungan kelas) di semua kelas mulai dari kelas satu sampai kelas enam masih banyak kekurangan-kekurangan, meskipun kekurangan disetiap kelas berbeda-beda. Supervisi akademik bukanlah penilaian unjuk kerja guru, apalagi bila tujuan utama penilaiannya semata-mata hanya dalam arti sempit, yaitu mengkalkulasi kualitas keberadaan guru dalam memenuhi kepentingan akreditasi guru belaka (Bahri, 2014). Permasalahan tersebut tentunya berpengaruh besar terhadap pelaksanaan proses pembelajaran juga hasil dan prestasi belajar siswa. Melalui kegiatan supervisi tersebut diharapkan terbaikinya proses belajar mengajar, yang di dalamnya melibatkan guru dan siswa, melalui serangkaian tindakan, bimbingan dan arahan (Dalawi, Zakso, \& Radiana, 2013). Oleh karena itu peneliti sebagai pembina berusaha menyelesaikan masalah 


\section{4 - Gulawentah: Jurnal Studi Sosial}

tersebut dengan berupaya meningkatan kompetensi guru dalam menyusun silabus dan RPP melalui Supervisi Akademik berkelanjutan di SDN 2 Ngadisanan Sambit Ponorogo.

\section{Metode Penelitian}

Penelitian ini menggunakan konsep naturalistik yaitu apa yang terjadi di kancah penelitian menjadi ukuran data yang paling bisa diterima. Penelitian ini dilaksanakan di SDN 2 Ngadisanan, Kecamatan Sambit Kabupaten Ponorogo. Penelitian ini dilaksanakan selama 1 tahun mulai Maret 2018 sampai dengan Maret 2019 di SDN 2 Ngadisanan Kecamatan Sambit Kabupaten Ponorogo. Pada penelitian ini, peneliti berusaha mendeskripsikan bentuk supervisi akademik untuk meningkatkan mutu pembelajaran guru terutama dalam menyususn RPP dan Silabus dengan menerapkannya pada pembelajaran maka dengan demikian data yang akan dikumpulkan dalam penelitian bersifat deskriptif yaitu mengenai uraian-uraian kegiatan supervisi akademik pembelajaran kepada guru dan penelitian ini menggunakan pendekatan kualitatif dengan jenis penelitian tindakan sekolah (PTK). Subyek penelitian ini adalah guru kelas I samapai dengan IV SDN 2 Ngadisanan Kecamatan Sambit Kabupaten Ponorogo yang berjumlah 6 guru kelas yang terdiri dari 2 guru tetap (PNS) dan 4 Guru Tidak Tetap (GTT).

Untuk memecahkan masalah penelitian yang disampaikan di depan, maka dilakukan tehnik pengumpulan data yaitu wawancara, observasi, dan dokumentasi. Penelitian ini memusatkan perhatian pada aspek pelaksanaan supervisi yang dimulai dari perencanaan, pengorganisasian, pelaksanaan, pengawasan dan evaluasi supervisi, dalam hal ini supervisi akademik yang dilaksanakan oleh kepala sekolah dalam meningkatkan mutu pembelajaran di SD Negeri 2 Ngadisanan. Penelitian tindakan kelas ini menggunakan model tindakan yang dikembangkan oleh Kemmis dan Mc Taggart (Wijaya Kusumah dan Dedi Dwitagama, 2010: 21), yang meliputi empat komponen yaitu: perencanaan (planning), tindakan (acting), pengamatan (observing), dan refleksi (reflecting). Keempat langkah tersebut saling terkait satu sama lain. Untuk menentukan keberhasilan penelitian ini dibutuhkan indikator kinerja penelitian yaitu: 
Tabel 1. Indikator Kinerja Penelitian

\begin{tabular}{lll}
\hline \multicolumn{1}{c}{ Rumusan Masalah } & \multicolumn{1}{c}{ Tujuan } & \multicolumn{1}{c}{ Indikator Kinerja } \\
\hline \multicolumn{1}{c}{$(1)$} & \multicolumn{1}{c}{$(2)$} & \multicolumn{1}{c}{$(3)$} \\
\hline $\begin{array}{l}\text { Apakah supervisi akademik } \\
\text { berkelanjutan bisa } \\
\text { meningkatkan kompetensi }\end{array}$ & $\begin{array}{l}\text { Untuk mengetahui } \\
\text { peningkatkan kompetensi } \\
\text { guru dalam menyusun RPP }\end{array}$ & $\begin{array}{l}\text { - Kompetensi guru dalam } \\
\text { penyusunan RPP dan silabus }\end{array}$ \\
$\begin{array}{l}\text { guru dalam menyusun RPP } \\
\text { dan silabus terhadap guru di }\end{array}$ & $\begin{array}{l}\text { dan silabus melalui } \\
\text { supervisi akademik }\end{array}$ & - Penerapan RPP yang telah \\
SDN 2 Ngadisanan & berkelanjutan SDN 2 & pembelajaran kegiatan \\
Kecamatan Sambit & Ngadisanan Kecamatan & $-80 \%$ guru mampu \\
Kabupaten Ponorogo? & Sambit kabupaten & menyusun RPP dan Silabus \\
& ponorogo. & $-75 \%$ mampu menrapkan \\
& & RPP yang telah disusun dlam \\
& & kegiatan pembelajaran \\
& &
\end{tabular}

Adapun rincian indikator keberhasilan dapat dijabarkan sebagai berikut: a) Sebanyak $80 \%$ guru di SDN 2 Ngadisanan mampu meninkatkan kompetensi dalam menyusun RPP dan silabus sebagai alat dalam pembelajaran. b) Sebanyak 75\% guru di SDN 2 Ngadisanan mampu menerapkan RPP dan silabus yang telah disusun dalam kegiatan pembelajaran.

Teknik analisis data yang digunakan adalah teknik analisis data kualitatif yakni: a) Reduksi data yang dilakukan peneliti dengan jalan membuat rangkuman inti. Data melalui wawancara dicatat dan direkam, selanjutnya diseleksi, dan disederhanakan sesuai dengan permasalahan yang diajukan dalam penelitian. B) Penyajian Data. penyajian data dilakukan dengan mengorganisasikan data yang telah direduksi yang berkaitan dengan fokus penelitian yaitu pelaksanaan supervisi akademik kepala sekolah. c. Penarikan Kesimpulan, setelah data disajikan selanjutnya dilakukan penarikan kesimpulan atau verifikasi dari data yang telah diperoleh. Penarikan kesimpulan dilakukan penelitisetelah dilakukan pengabsahan data. d. Data Kualitatif, data kualitatif digunakan untuk menentukan peningkatan proses belajar khususnya berbagai tindakan yang dilakukan oleh guru. Data kualitatif berupa data hasil belajar, catatan lapangan, hasil observasi keterampilan guru serta aktivitas siswa dalam pembelajaran IPS. Data kualitatif dipaparkan dalam kalimat yang dipisahkan menurut kategori untuk memperoleh kesimpulan.

\section{Hasil dan Pembahasan}

Untuk mendapatkan informasi awal maka digunakan data hasil penilaian diri sendiri. Sehingga didapatkan data sebagai berikut: 
Tabel 2. Hasil Pra Observasi Kompetensi Guru

\begin{tabular}{clcc}
\hline \multirow{2}{*}{ No } & Perangkat Pembelajaran & $\begin{array}{c}\text { Nilai } \\
\text { Pra Observasi }\end{array}$ & Klasifikasi \\
\hline 1 & Administrasi Pembelajaran & $79 \%$ & Cukup \\
\hline 2 & Penelaahan RPP & $65 \%$ & Kurang \\
\hline 3 & Penilaian Pelaksanaan Pembelajaran & $67 \%$ & Kurang \\
\hline 4 & Administrasi Penilaian Pembelajaran & $81 \%$ & Baik \\
\hline 5 & Administrasi Pengelolaan Kelas & $82 \%$ & Baik \\
\hline
\end{tabular}

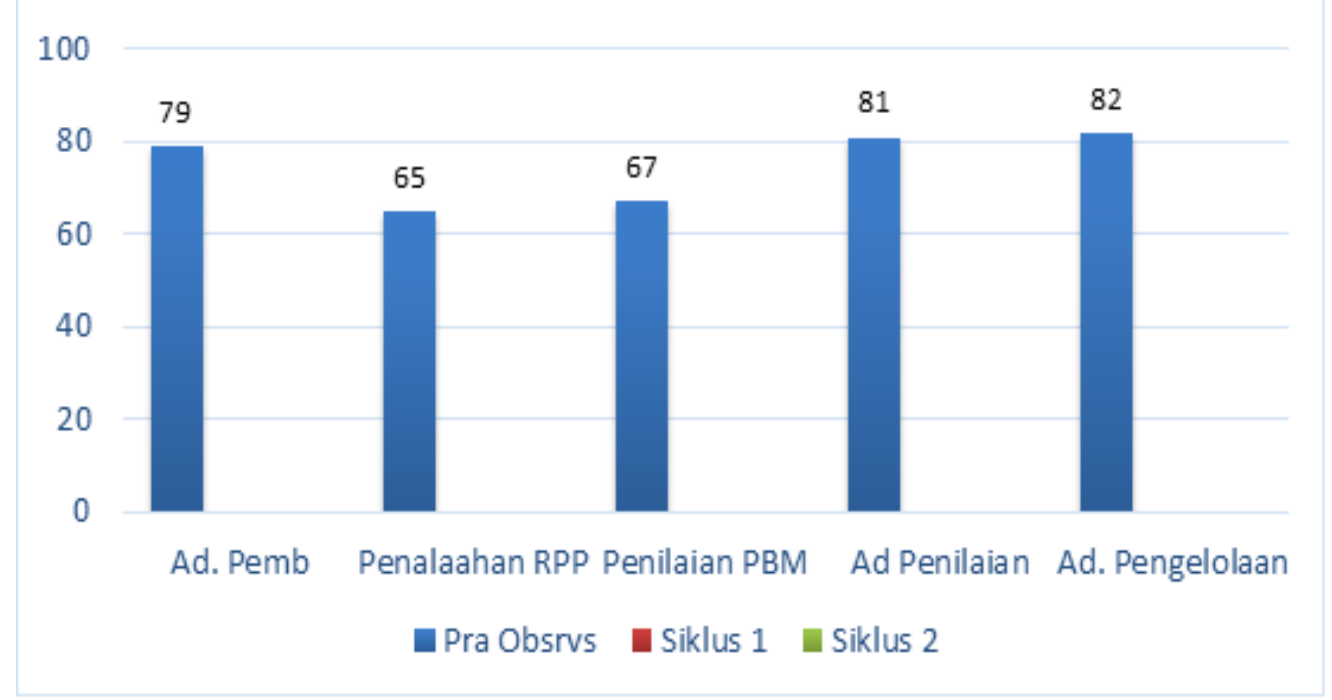

\section{Gambar 1. Hasil Prasiklus}

Dari hasil pra observasi yang dilakukan maka dapat dikatakan bahwa Perangkat Pembelajaran yang dibuat oleh guru yang didalamnya memuat telaah RPP dan penilaian pelaksanaan pembelajaran mendapat katagori paling rendah yaitu kurang dibandingkan dengan kompetensi lainnya meskipun administrasi pembelajaran yang lain masih dalam katagori cukup dan baik. Akan tetapi semua administrasi pembelajaran juga sangat berpengaruh antara satu dengan yang lain. Oleh karena itu Kompetensi Penelaahan RPP dan Penilaian Pelaksanaan Pembelajaran perlu adanya perbaikan. 
Telaah RPP yang dilakukan pada fase praobservasi dari guru kelas 1 sampai dengan 6 diperoleh data sebagai berikut:

Tabel 2. Hasil Telaah RPP Praobsevasi

\begin{tabular}{cccl}
\hline No & Guru & Skor Diperoleh & Kreteria \\
\hline 1 & Guru Kelas 1 & 65 & Kurang \\
\hline 2 & Guru Kelas 2 & 65 & Kurang \\
\hline 3 & Guru Kelas 3 & 63 & Kurang \\
\hline 4 & Guru Kelas 4 & 72 & Kurang \\
\hline 5 & Guru Kelas 5 & 63 & Kurang \\
\hline 6 & Guru Kelas 6 & 63 & Kurang \\
\hline \multirow{2}{*}{ Jumlah } & 391 & Kurang
\end{tabular}

Dari kondisi tersebut di atas maka pada peneilitian ini difokuskan pada kompetensi yang paling rendah yaitu pada kompetensi dalam menyusun Penyusunan atau Penelaahan RPP yang disesuaikan dengan Silabus dan Penilaian Pelaksanaan Pembelajaran dengan nilai $65 \%$ dan 67\% dalam klasifikasi kurang pada kegiatan pra observasi. Dari hasil pra observasi yang dilaksanakan di SDN 2 Ngadisanan ternyata semua guru lemah dalam penyusunan RPP dan Pelaksanann Pembelajaran yang tentunya merupakan implementasi dari RPP tersebut. Dari data nilai pada poin penelaah RPP dan penilaian pelaksanaan pembelajaran semua guru yang terdiri dari 6 kelas dalam klasifikasi kurang sedangkan administrasi yang lain masih dalam klasifikasi cukup. Dari data hasil pra observasi maka ditindaklanjuti dengan pemecahan masalah yaitu supervisi akademik. Supervisi akademik dengan teknik supervisi kelompok yaitu mengelompokan guru yang memiliki masalah yang sama dalam hal ini adalah penyusunan RPP yang diutamakan dengan tujuan memperbaiki penilaian pelaksanaan pembelajaran dikelompokkan kemudian dilaksanakan pertemuan.

\section{Siklus I}

Dalam membantu mengatasi kesulitan guru berdasarkan pengamatan praobservasi dipecahkan dengan supervisi akademik dengan dua tahapan tindakan yaitu: Tahapan pertama, guru yang memiliki kompetensi penyususnan RPP dalam kategori kurang dikelompokkan kemudian dilaksanakan supervisi kelompok dengan teknik pertemuan guru. Tahap kedua, guru yang lemah dalam penyusunan RPP tersebut diadakan tindakan supervisi akademik dengan teknik kunjungan kelas. 


\section{8 - Gulawentah: Jurnal Studi Sosial}

Jumlah skor pengumpulan data pada guru kelas 1 s.d kelas 6 sebagai contoh untuk perolehan data pada siklus I adalah $=58$. Dengan demikian kompetensi guru pada telaah RPP dan Supervisi di lapangan serta menurut hasil kunjungan kelas adalah $57: 72 \times 100 \%=79 \%$ dan kriteria yang ditetapkan adalah cukup. Demikian juga guru yang lain apabila di rata-rata dari hasil telaah RPP guru kelas 1 sampai dengan kelas 6. Dengan demikian berdasarkan data pada siklus pertama maka klasifikasi kompetensi guru dalam penyusunan RPP dan Silabus dalam kategori cukup. Hal tersebut dapat dilihat dari data telaah RPP dari guru kelas 1 sampai dengan 6 berikut ini.

Tabel 3. Hasil Telaah RPP Siklus 1

\begin{tabular}{llll}
\hline No & Guru & Skor Diperoleh & Kreteria \\
\hline 1 & Guru Kelas 1 & 81 & Baik \\
\hline 2 & Guru Kelas 2 & 82 & Cukup \\
\hline 3 & Guru Kelas 3 & 79 & Cukup \\
\hline 4 & Guru Kelas 4 & 78 & Cukup \\
\hline 5 & Guru Kelas 5 & 81 & Cukup \\
\hline 6 & Guru Kelas 6 & 79 & Cukup \\
\hline Jumlah & & 479 & \\
\hline Rata-rata & 80 & Cukup \\
\hline
\end{tabular}

Pada Siklus 1 ini grafik Penelaahan RPP meningkat karena setelah diadakan perbaikan penyusunan RPP dan Silabus menjadi lebih baik walaupun masih dalam kreteria cukup. Peningkatan kemampuam penyusunan RPP dan silabus tentunya berpengaruh pula pada kompetensi yang lain. Hal tersebut dan kita lihat capain pada siklus I di bawah ini :

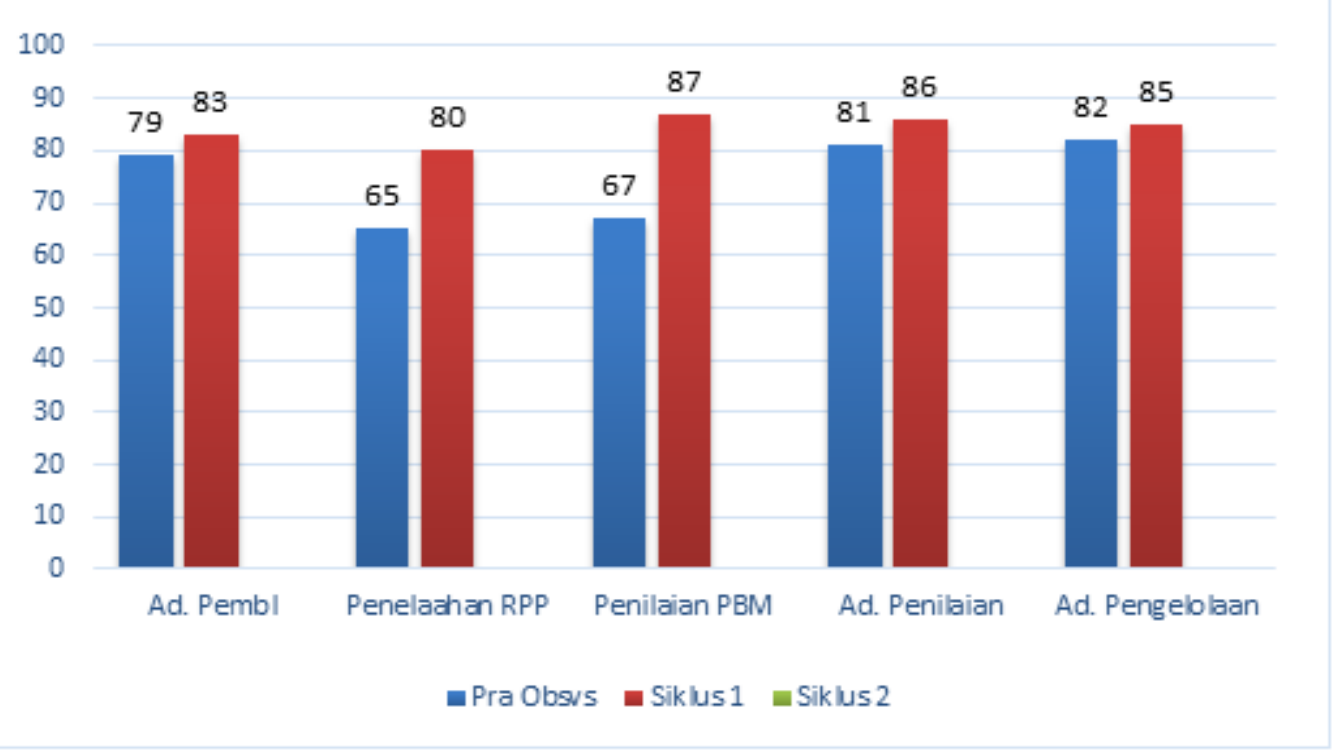

Gambar 2. Telaah RPP Siklus I 
Pada siklus pertama menunjukan bahwa antusias guru dalam memecahkan permasalahan yang sedang dihadapi menunjukan ada keseriusan. Hal tersebut tampak pada saat tindakan pertama diaplikasikan yaitu supervisi kelompok dengan teknik pertemuan guru yang pesertanya adalah enam orang guru yang memiliki kesamaan permasalahan yaitu kompetensi dalam penyusunan RPP dan Silabus. Pada pertemuan enam guru tersebut setiap guru tampak antusias dalam mengikuti tahapan demi tahapan yaitu membahas tentang lima kompetensi guru dalam pembelajaran secara umum yaitu Administrasi Pembelajaran, Penelaahan RPP, Penilaian Pelaksanaan pembelajaran, Administrasi Penilaian, dan Administrasi Pengelolaan Kelas. Pertemuan guru terfokus pada elemen kompetensi dan diskripsi kompetensi serta indikator kompetensi penyusunan atau Penelaahan RPP dan Silabus.

Tindak lanjut dan pertemuan guru diteruskan dengan supervisi akademik individual dengan teknik kunjungan kelas. Hasil refleksi terhadap kompetensi telaah RPP dan penilaian pelaksanaan pembelajaran guru pada saat kunjungan kelas awalnya guru kelihatan salah tingkah pada saat dikunjungi, tetapi akhirnya guru mampu menguasai sehingga menjadi biasa dan para siswa kelihatan lebih semangat karena masing-masing guru berupaya mengaplikasikan kompetensi RPP yang telah disusun setiap tahapan secara keseluruhan ada peningkatan kompetensi dalam kegiatan pembelajaran. Diantaranya adalah guru bersikap lebih objektif terhadap peserta didik. Mampu menguasai kelas dan menguasai materi pelajaran serta mampu menggunakan berbagai pendekatan/metoda yang bervariasi. Akan tetapi masih ada item yang belum teratasi secara maksimal pada telaah RPP diantaranya adalah masih kaku dalam menggunakan alat peraga dan masih memegang buku sumber sambil membaca. Kendala-kendala tersebut akan ditindaklanjuti pada siklus kedua. Kegiatan supervisi akademik jika dilaksanakan secara berkala dapat meningkatkan kompetensi pedagogik guru (Prihono, 2014).

\section{Siklus II}

Hasil Kunjungan kelas siklus II dilaksanakan dari tgl. 11 s/d 16 Februari 2019. dengan fokus tetap sama yaitu kompetensi penyusunan RPP pada inctrumen telaah RPP maka didapat data seperti pada tabel berikut:

Tabel 4 Hasil Telaah RPP Siklus 2

\begin{tabular}{clcc}
\hline No & Guru & Skor Diperoleh & Kreteria \\
\hline 1 & Guru Kelas 1 & 88 & Baik \\
\hline 2 & Guru Kelas 2 & 89 & Baik \\
\hline 3 & Guru Kelas 3 & 89 & Baik \\
\hline 4 & Guru Kelas 4 & 81 & Baik \\
\hline 5 & Guru Kelas 5 & 81 & Baik \\
\hline 6 & Guru Kelas 6 & 82 & Baik \\
\hline
\end{tabular}




\begin{tabular}{lccc}
\hline & Jumlah & 508 & \\
\hline Rata-rata & 85 & Baik \\
\hline
\end{tabular}

Indikator Keberhasilan Telaah RPP Guru pada Siklus 2, Seperti halnya pada siklus 1 hasil Supervisi dan observasi telaah RPP pada siklus 2 diperoleh jumlah skor kriterium (bila setiap butir mendapat skor tertinggi 3, ada 24 dari objek item instrumen penelitian guru) maka akan diperoleh skor keseluruhan $3 \times 24-=72$, akan tetapi pada kenyataan di lapangan masih ada beberapa item yang masih memperoleh skor 2 meskipun berkurang dibandingkan siklus 1 .

Jumlah skor pengumpulan data pada guru kelas satu sampai 6 sebagai contoh untuk perolehan data pada siklus I adalah $=59$. Dengan demikian kompetensi guru pada telaah RPP dan Supervisi di lapangan serta menurut hasil kunjungan kelas adalah $59: 72 \times 100 \%=82 \%$ dan kriteria yang ditetapkan adalah baik. Demikian juga guru yang lain apabila di rata-rata dari hasil telaah RPP guru kelas 1 sampai dengan kelas 6. Dengan demikian berdasarkan data pada siklus satu maka klasifikasi kompetensi guru dalam penyusunan RPP dan Silabus dalam kategori baik. Supervisi akademik kepala sekolah dapat meningkatkan Kompetensi Guru dalam menyusun Rencana Pelaksanaa Pembelajaran (Arman, 2017). Guru-guru merespon positif supervisi akademik oleh kepala sekolah karena kegiatan supervisi sangatlah penting dilakukan untuk mengubah kinerja guru menjadi lebih baik (Leniwati \& Arafat, 2017). Hal tersebut dapat dilihat dari data telaah RPP dari guru kelas 1 sampai dengan 6 berikut ini.

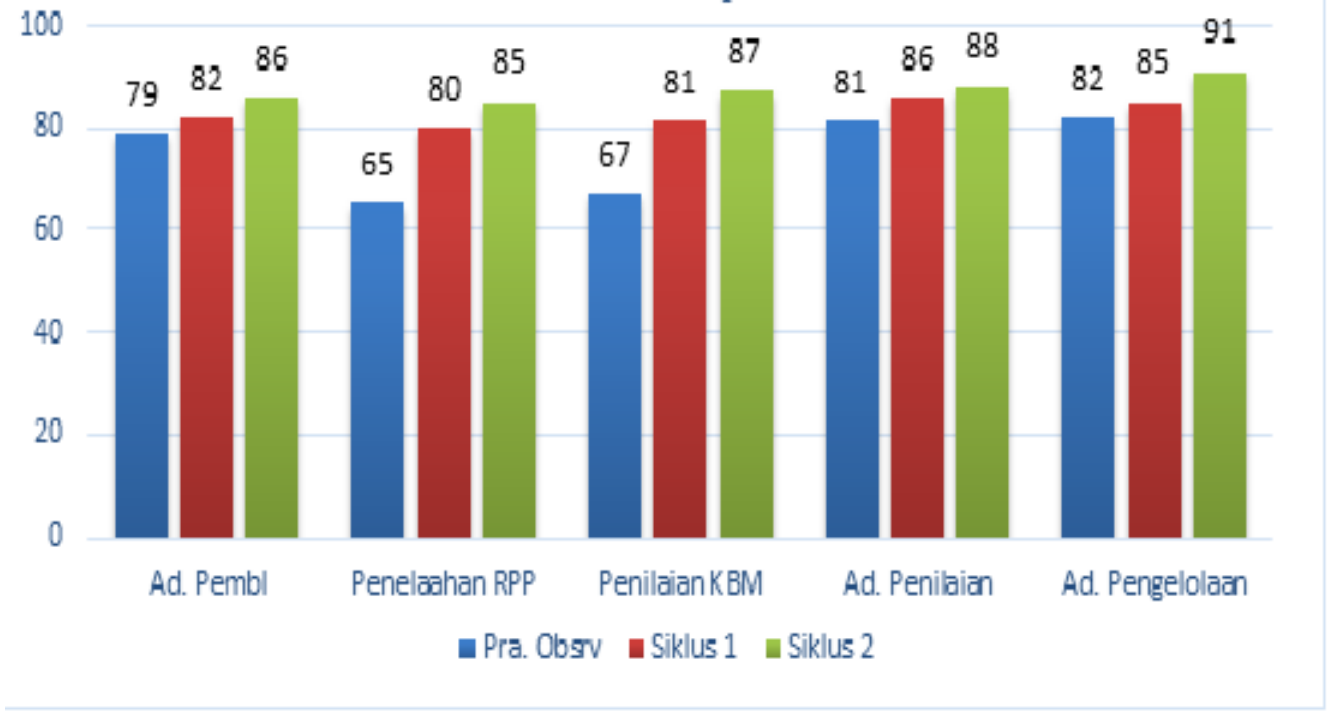

\section{Gambar 3. Telaah RPP Siklus II}

Kegiatan belajar mengajar pada siklus kedua guru sudah tampak biasa bahkan lebih kelihatan semangat untuk mengaplikasikan indikator-indikator dalam penyusunan RPP, Permaslahan-permasalahan yang dihadapi selama ini sudah terselesaikan dan terpecahkan dengan baik. Hal tersebut tampak pada mobilitas guru tidak canggung dan diterapkan dalam pembelajaran siswa. Disamping itu siswa belajar lebih semangat, karena guru dalam menyampaikan materi pembelajaran sangat menarik dan terjadi interaksi yang sangat baik. Data yang dihasilkan pada siklus II ternyata sudah memenuhi indikator keberhasilan penelitian, sehingga penelitian tidak perlu dilanjutkan ke siklus berikutnya. Kegiatan supervisi akademik yang diaktualisasikan dalam supervisi kepala sekolah dapat meningkatkan kinerja guru dengan tujuan mempertinggi kualitas proses pembelajaran demi tercapainya mutu pendidikan yang diharapkan (Ramadhan, 2017). Menurut 
(Hardono, Haryono, \& Yusuf, 2017) terdapat pengaruh kepemimpinan kepala sekolah dan supervisi akademik terhadap motivasi kerja baik secara parsial maupun simultan. Kepemimpinan Kepala Sekolah berpengaruh positif signifikan terhadap Kinerja Guru baik secara langsung maupun tidak langsung (Ndapaloka, Hardyanto, \& Prihatin, 2016). Kepemimpinan seorang kepala sekolah dilihat dari cara memperlakukan sumberdaya manusia dengan bijaksana. Hal ini berdampak pada hasil kerja yang dicapai oleh guru atau pendidik yang ada didalam satuan pendidikan(Astuti \& Dacholfany, 2016).

\section{Simpulan}

Supervisi akademik berkelanjutan dapat meningkatkan kompetensi guru kelas satu sampai kelas 6 dalam menyusun RPP dan silabus di SD Negeri 2 Ngadisanan Kecamatan Sambit Kabupaten Ponorogo. Tahap praobservasi, menunjukkan bahwa kemampuan guru dalam menyusun RPP dan silabus masih dalam kategori kurang nilai rata-rata komptensi dalam telaah RPP kelas satu sampai kelas enam adalah $65 \%$. Pada siklus I, kompetensi guru dalam telaah RPP setelah diadakan supervisi nilai rata-rata mencapai $80 \%$ meskipun masih dalam kreteria cukup.. Pada siklus II, dengan didakan refleksi dan perbaikan kompetensi guru dalam menyusun RPP mulai terlihat lebih baik terbukti dari nilai rata-rat dalam telaah RPP mencapai nilai $85 \%$ dengan kategori baik.

\section{Daftar Pustaka}

Arman, A. (2017). Upaya Peningkatan Kompetensi Guru dalam Menyusun Rencana Pelaksanaan Pembelajaran Melalui Supervisi Akademik Kepala Sekolah Di SMAN 1 Lembah Melintang Kabupaten Pasaman Barat. Jurnal Manajemen Pendidikan, 1(1), 55-62.

Astuti, R., \& Dacholfany, M. I. (2016). Kepemimpinan Kepala Sekolah Terhadap Kinerja Guru di Kota Metro Lampung. Jurnal Lentera Pendidikan Pusat Penelitian LPPM UM METRO, 1(2), 204-217.

Bahri, S. (2014). Supervisi akademik dalam peningkatan profesionalisme guru. Visipena Journal, $5(1), 100-112$.

Dalawi, D., Zakso, A., \& Radiana, U. (2013). Pelaksanaan supervisi akademik pengawas sekolah sebagai upaya peningkatan profesionalisme guru SMP Negeri 1 Bengkayang. Jurnal Pendidikan Dan Pembelajaran, 2(3), 1-16.

Hardono, H., Haryono, H., \& Yusuf, A. (2017). Kepemimpinan Kepala Sekolah, Supervisi Akademik, dan Motivasi Kerja dalam Meningkatkan Kinerja Guru. Educational Management, $6(1), 26-33$.

Leniwati, L., \& Arafat, Y. (2017). Implementasi Supervisi Akademik Kepala Sekolah Untuk Meningkatkan Kinerja Guru, 1(1), 325-343. Retrieved from The Value of Pancasila, National Insight, PPKn Subject

Ndapaloka, V., Hardyanto, W., \& Prihatin, T. (2016). Pengaruh Supervisi Akademik Pengawas Dan Kepemimpinan Kepala Sekolah Melalui Motivasi Berprestasi Sebagai Mediasi Terhadap Kinerja Guru Smk Negeri Kabupaten Ende. Educational Management, 5(1), 42-54.

Prihono, H. (2014). Model Supervisi Akademik Berbasis Evaluasi Diri Melalui MGMP Sekolah Untuk Meningkatkan Kompetensi Pedagogik Guru SMK di Kabupaten Wonogiri. Educational Management, 3(2), 126-132.

Ramadhan, A. (2017). Pengaruh Pelaksanaan Supervisi Akademik Pengawas Sekolah Dan Supervisi Kepala Sekolah Terhadap Kinerja Guru SMK Negeri Di Kabupaten Majene. Journal of Educational Science and Technology (EST), 3(2), 136. https://doi.org/10.26858/est.v3i2.3579 
Rosilawati, T. (2014). Supervisi Akademik dalam Upaya Peningkatan Motivasi Guru Menyusun Perangkat Persiapan Pembelajaran. Jurnal Penelitian Tindakan Sekolah Dan Kepengawasan, $1(2), 57-62$.

Sudin, A. (2008). Implementasi Supervisi Akademik Terhadap Proses Pembelajaran di Sekolah Dasar Se Kabupaten Sumedang. Jurnal Pendidikan Dasar, 9(April), 1-4. 